\title{
Biomimetic synthesis of copper nanoparticles using rhizome extract of Corallocarbus epigaeus and their bactericidal with photocatalytic activity
}

\author{
Kandasamy Selvam ${ }^{1} \cdot$ Chinnappan Sudhakar $^{1} \cdot$ Thangasamy Selvankumar $^{1} \cdot$ Balakrishnan Senthilkumar $^{2}$. \\ Rathakrishnan Selva Kumar ${ }^{3}$. Nallakumar Kannan ${ }^{1}$
}

Received: 21 November 2019 / Accepted: 22 April 2020 / Published online: 6 May 2020

(c) Springer Nature Switzerland AG 2020

\begin{abstract}
The present study demonstrates the green synthesis of copper nanoparticles (CuNPs) from Corallocarbus epigaeus rhizome extract and its antioxidant and antibacterial activity against multi-drug resistant Salmonella enterica serovar Typhi. Biogenic CuNPs were characterized by UV-Visible spectroscopy, transmission electron microscopy, Fourier transform-Infrared spectroscopy, X-ray diffraction, scanning electron microscopy with energy-dispersive X-ray spectroscopy. Obtained results confirmed spherical shaped CuNPs with an average diameter of $65-80 \mathrm{~nm}$. Dose-dependent $(2-10 \mathrm{mM})$ growth assay of Salmonella enterica serovar Typhi showed effective inhibition mechanism of CuNPs. The CuNPs exhibited tremendous degradation efficiency for the methylene blue (MB) almost 90\% removal in 75 min illumination.
\end{abstract}

Keywords Antibacterial activity · Antioxidant activity $\cdot$ Photocatalytic activity $\cdot$ Corallocarbus epigaeus rhizome $\cdot$ CuNPs

\section{Introduction}

In recent times, nanosize-based materials and/or nanomaterials were extensively studied because of their unique properties and applications in the fields of science and technology and medicine [1] In particular, metal nanoparticles have received significant attention due to their optical and electromagnetic properties [11]. Among the various metal nanoparticles, copper nanoparticles (CuNPs) have attracted tremendous attention due to their significant physicochemical, optical, catalytic and heat transfer properties $[6,14]$. Moreover, CuNPs has been applied in various fields, including solar cells [16], energy storage [3], dye degradation [17], chemical manufacturing [37], and medicinal application [33].
The chemical mediated CuNPs synthesis involves the use of toxic chemicals which may pollute the environment [26]. Thus, non-toxic, low cost and eco-friendly nature have received great attraction to the researchers because of simple methodology, rapid synthesis, and improved stability compared to physicochemical methods. Several studies have been reported on the synthesis of CuNPs using the biological materials such as bacteria [10] fungi [4], edible mushroom [19] and plant extracts [5, 31]. Among the various biological resources, plant, and plant-derived materials are commonly used for CuNPs synthesis because of their ease of availability, cost-effective, compatibility and easy scale-up for commercial scale. Several plants and plant-derived materials such as Azadirachta indica [5], Cissus quadrangularis [21], Quisqualis indica [20], Syzygium aromaticum bud extract

Kandasamy Selvam, ksk.selvam@gmail.com | ${ }^{1}$ PG \& Research Department of Biotechnology, Mahendra Arts and Science College (Autonomous), Kalippatti, Namakkal, Tamil Nadu 637501 , India. ${ }^{2}$ Department of Medical Microbiology, College of Health and Medical Sciences, Haramaya University, P.O. Box 235, Harar, Ethiopia. ${ }^{3}$ PG \& Research Department of Chemistry, Mahendra Arts and Science College (Autonomous), Kalippatti, Namakkal, Tamil Nadu 637 501, India. 
[24], and also many rhizomes like, Rheum palmatum L. rhizome extract [18], and ginger and garlic extracts ElRefai et al. [7] have been used for the synthesis of CuNPs. However, there are no reports on the synthesis of CuNPs using the rhizome extract of Corallocarbus epigaeus.

Corallocarbus epigaeus is a traditional medicinal plant practiced by ancient Siddha and Ayurvedic medicine for the treatment of snake bites, asthma, rheumatism, and also for the syphilitic disease. The shoot system of the plant is commonly used for medicinal practices, whereas rhizome is very effective compared to the shoot system. The rhizome is bitter in taste and contains many phytochemicals such as carbohydrate, phenols, steroids, sterols, alkaloid, saponin, tannins, and flavanoids [22] reported that C. epigaeus extract has both antioxidant and antimicrobial activity because the extract contains several phytochemicals and secondary metabolites. Since the C. epigaeus contains several phytochemicals and/or secondary metabolites, it could be used as biological reducing agents for CuNPs synthesis. However, the C. epigaeus rhizome extract mediated synthesis of CuNPs with effective antibacterial activity against MDR strain has not been reported previously. Hence, the objectives of the present study were (i) synthesis and characterization of CuNPs using C. epigaeus rhizome extract, and (ii) assess the antioxidant and antibacterial potential of CuNPs against multidrug-resistant (MDR) Salmonella enterica serovar Typhi (iii) evaluate the photocatalytic degradation of methylene blue (MB).

\section{Materials and methods}

\subsection{Plant material and chemicals}

The fresh rhizome of C. epigaeus was collected from Yercaud hills $\left(11.8309^{\circ} \mathrm{N}, 78.2305^{\circ} \mathrm{E}\right)$, Tamil Nadu, India. The rhizome was thoroughly washed several times with tap water to remove the dust particles, shade dried for one week to remove the residual moisture, and ground to form a powder. The powder was stored in an airtight container at $4{ }^{\circ} \mathrm{C}$ and used for further studies. All other chemicals used in this study were of analytical grade and were purchased from Hi-Media Laboratories Pvt. Ltd (Mumbai, India).

\subsection{Corallocarbus epigaeus rhizome extracts preparation}

The rhizome powder $(5 \mathrm{~g})$ was dissolved in $100 \mathrm{~mL}$ of distilled water and boiled for $30 \mathrm{~min}$ at $50^{\circ} \mathrm{C}$. The extract was filtered by Whatman No.1 filter paper, and the filtrate was used for CuNPs synthesis.

\subsection{Synthesis of CuNPs}

The CuNPs were synthesized according to [25] with minor modifications. Freshly prepared $\mathrm{CuSO}_{4}$ solution $(5 \mathrm{mM})(90 \mathrm{~mL})$ was mixed with $10 \mathrm{~mL}$ of $C$. epigaeus rhizome extract in a $250 \mathrm{~mL}$ Erlenmeyer flask with constant stirring on a magnetic stirrer at $80-100^{\circ} \mathrm{C}$. Colour change of the reaction mixture was observed from deep blue to colourless and then to brick red and dark red on vigorous stirring for $12 \mathrm{~h}$. The CuNPs were separated by centrifuging at 10,000 rpm and dried in the open air for $24 \mathrm{~h}$. To optimize the experimental variables, CuNPs synthesis was conducted at various concentrations of rhizome extract (10-40 $\mathrm{mL})$.

\subsection{Characterization of CuNPs}

Corallocarbus epigaeus rhizome extract mediated CuNPs were visually monitored and an absorbance spectrum was recorded using a UV-Visible spectrophotometer (Elico-164 PC) in the range of $200-500 \mathrm{~nm}$. The size and morphology of synthesized CuNPs were observed by transmission electron microscope (TEM, FEI Tecnai TF 20 high resolution). The elemental composition of the particles was analyzed by scanning electron microscopeenergy dispersive X-ray analysis (SEM-EDX- Jeol JSM 6390). Fourier transform-Infrared spectroscopy (FT-IR Shimadzu-8400) analysis was performed to understand the role of $C$. epigaeus biomolecules in the metal reduction. FT-IR spectrums were recorded with a range of $400-4000 \mathrm{~cm}^{-1}$. X-ray diffraction (XRD) was recorded in the $2 \theta$ range of $30-80^{\circ}$ using XRD6000, (Shimadzu) of $\mathrm{Cu}$ Ka radiation, the energy of which was $8.04 \mathrm{keV}$ and wavelength was $1.54 \mathrm{~A}$.

\subsection{Antioxidant assay}

Antioxidant potential of rhizome extract and biosynthesized CuNPs was evaluated by 2, 2-diphenyl-1-picrylhydrazyl-hydrate (DPPH) dot-blot method [29, 30]. The radical scavenging capacity towards DPPH was tested using thin-layer chromatographic (TLC) plates (Merck). Briefly, $10 \mu \mathrm{L}$ of CuNPs sample was spotted onto TLC plates with the help of a microcapillary tube and allowed to dry for 3-5 min. The staining of silica gel TLC plates was carried out by placing them upside down for $10 \mathrm{~s}$ in $0.004 \%$ DPPH solution. The excess solution was removed with the blotting paper, and the plates were air-dried. The 
formation of coloured zones on the TLC plate indicates the antioxidant potential of CuNPs.

\subsection{Antibacterial assessment}

The antibacterial activity of CuNPs was assessed according to Govarthanan et al. [9] against multidrug-resistant (MDR) Salmonella enterica serovar Typhi (Accession No. KT037135). The MDR bacteria were inoculated in nutrient broth supplemented with different concentrations of CuNPs (2-10 mM), and the flasks were incubated at $37^{\circ} \mathrm{C}$ for $12 \mathrm{~h}$. The samples were collected at regular time intervals, and the bacterial growth rate was measured in terms of an increase in optical density (OD) at $600 \mathrm{~nm}$. Control experiments were carried out in the absence of CuNPs.

\subsection{Degradation of Methylene blue}

The photocatalytic activity (PCA) of biosynthesized CuNPs was assayed by the degradation of methylene blue (MB) under sunlight irradiation as previously reported by Singh et al. [32] and Kayalvizhi et al. [13]. About $20 \mathrm{mg}$ of biosynthesized CuNPs was added to $100 \mathrm{~mL}(100 \mathrm{mg} / \mathrm{L})$ of MB while the control contained only for MB. The dye suspension was mixed thoroughly using a shaker for $1 \mathrm{~h}$ in dark condition. After, the subsequent mixture was allowed to remain underneath the sunlight and the intensity $850 \mathrm{~W} /$ $\mathrm{m}^{2}$ between 10:00 and 11:15 am. At specified point intervals, $5 \mathrm{~mL}$ the dye sample was taken, and centrifuged at $10,000 \mathrm{rpm}$ for $10 \mathrm{~min}$, and the absorbance range (200-700 nm) was estimated using a UV-Visible spectrophotometer (Elico-164 PC). The degradation efficiency (\%) has been determined by the following Equation.

Degradation Efficiency $(\%)=\left(\frac{C_{0}-C_{t}}{C_{0}}\right) \times 100$

where, $C_{0}$ is the initial concentration and $C_{t}$ are final $M B$ concentrations with time $t$ in the aqueous phase, respectively.

\section{Results and discussion}

The colour change of the reaction mixture from deep blue to brick red after $12 \mathrm{~h}$ of incubation primarily indicates the conversion of $\mathrm{Cu}$ into CuNPs. Figure 1 shows the UV spectra of biosynthesized CuNPs using a different concentration of $C$. epigaeus rhizome aqueous extract. The broad peak obtained at $280 \mathrm{~nm}$ further confirmed the formation of CuNPs. The results are consistent with the previous studies reported the surface plasmon resonance of CuNPs at

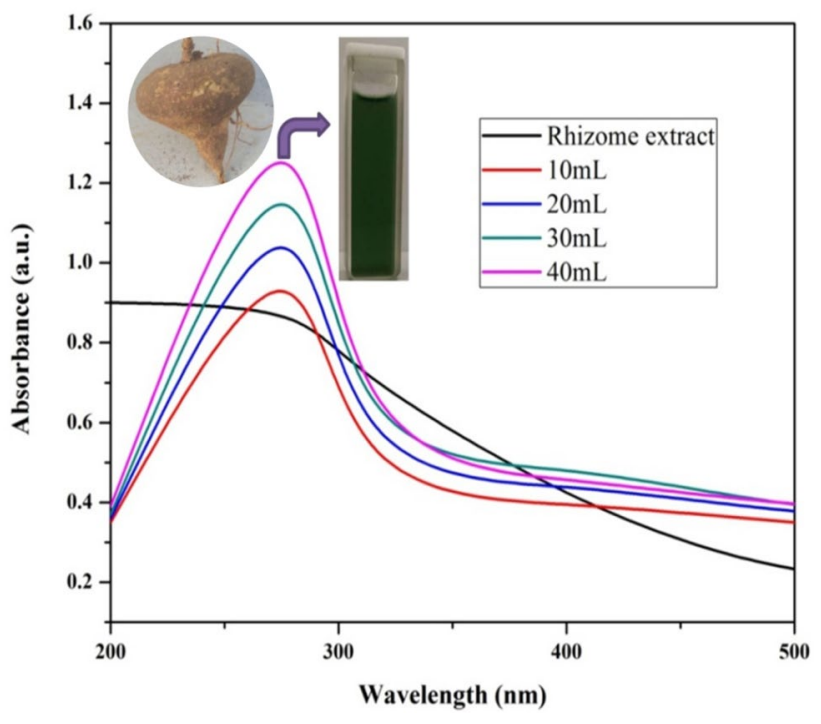

Fig. 1 UV-Vis spectra of biosynthesized CuNPs and rhizome extract

$280 \mathrm{~nm}[23,36]$. TEM image (Fig. 2a) of the synthesized CuNPs shows the spherical, relatively uniform shape and size distribution of nanoparticles with a diameter range of $65-80 \mathrm{~nm}$. This is very similar to those described in the previous report [25]. Figure $2 b$ shows the SEM image of the particles is uniform distribution, nearly spherical in shape. The EDX showed in Fig. $2 \mathrm{~b}$ revealed the strong signal in the copper region and confirmed the formation of CuNPs. CuNPs generally show a typical visual absorption peak around at 1 and $8 \mathrm{keV}$ due to surface Plasmon resonance and also indicate that bio-synthesized CuNPs were free from impurity [5].

The C. epigaeus rhizome extract having bioactive compounds that might play a responsibility in the CuNPs synthesis can be confirmed by FT-IR spectrum [28]. Figure 3 a represents the FT-IR spectra of $C$. epigaeus rhizome extract. The FT-IR analysis shows different characteristics peaks at $3441.16,2923.0425,2858.63,2360.01,1649.21$, $1457.28,1157.34,1025.21,778.28 \mathrm{~cm}^{-1}$ between the range $400-4000 \mathrm{~cm}^{-1}$. It was observed that peaks appeared at $3441.16 \mathrm{~cm}^{-1}$ corresponded to the phenolic $\mathrm{O}-\mathrm{H}$ group of rhizome extract. The peak appeared at $2923.04 \mathrm{~cm}^{-1}$ was associated with $\mathrm{C}-\mathrm{H}$ vibrations. The bands appearing at $1649.21 \mathrm{~cm}^{-1}$ and $1457.28 \mathrm{~cm}^{-1}$ are attributed to the formation of oxygen functional groups like highly conjugated $(C=0)$ stretching in carboxylic groups. The peak at $1025.21 \mathrm{~cm}^{-1}$ has corresponded to the presence of $\mathrm{C}-\mathrm{O}$ stretching vibrations in the ester group present in the rhizome extract. The broad band $3441.16 \mathrm{~cm}^{-1}$ is changed to $3433.44 \mathrm{~cm}^{-1}$ (Fig. $3 \mathrm{~b}$. In addition; the prominent bands at 590.24 and $461.01 \mathrm{~cm}^{-1}$ confirm the presence of the $\mathrm{Cu}$ vibration in the biosynthesized CuNPs $[15,27,33]$. 


\section{a}
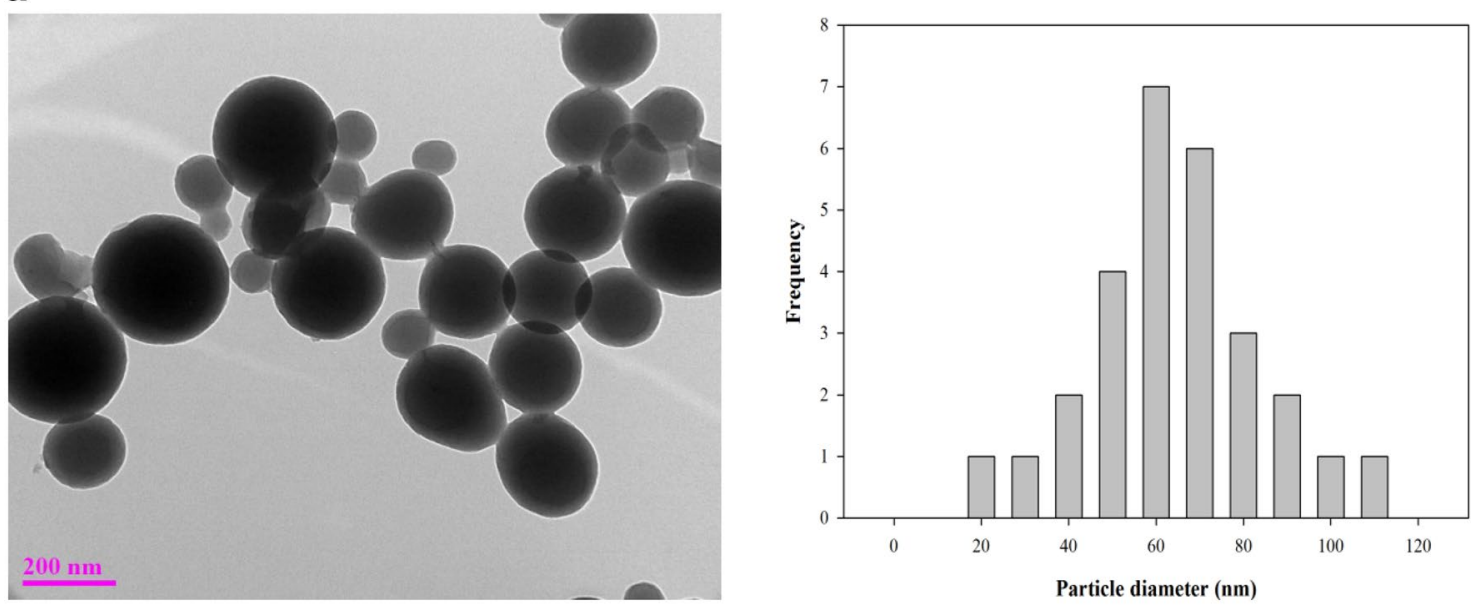

b
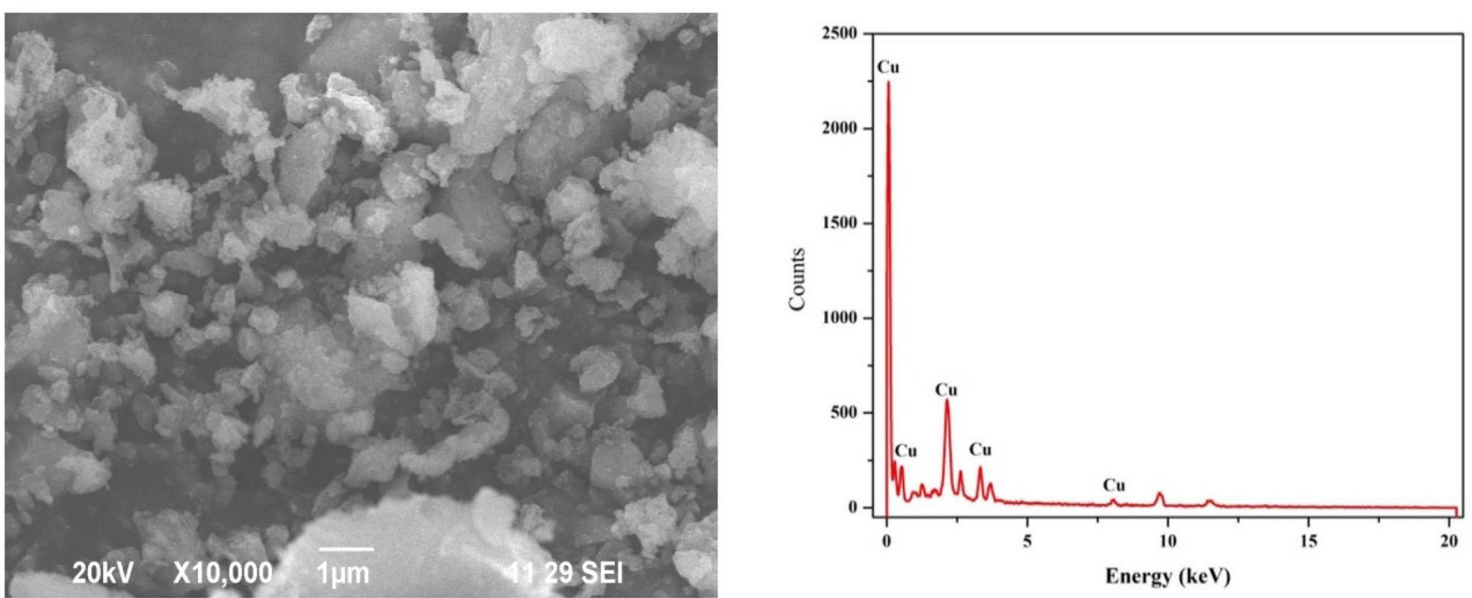

Fig. 2 a TEM with histogram and b SEM-EDS images of CuNPs synthesized from rhizome extract

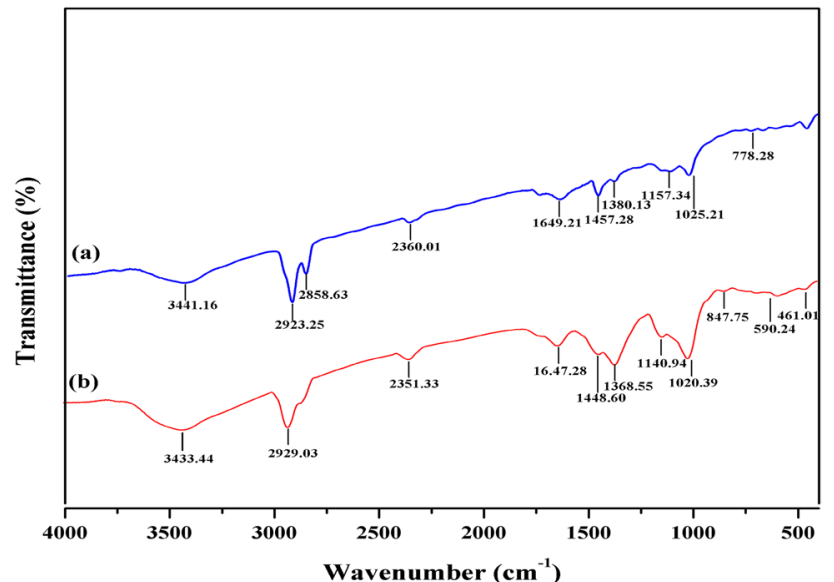

Fig. 3 FT-IR spectra of a rhizome extract and $\mathbf{b}$ CuNPs

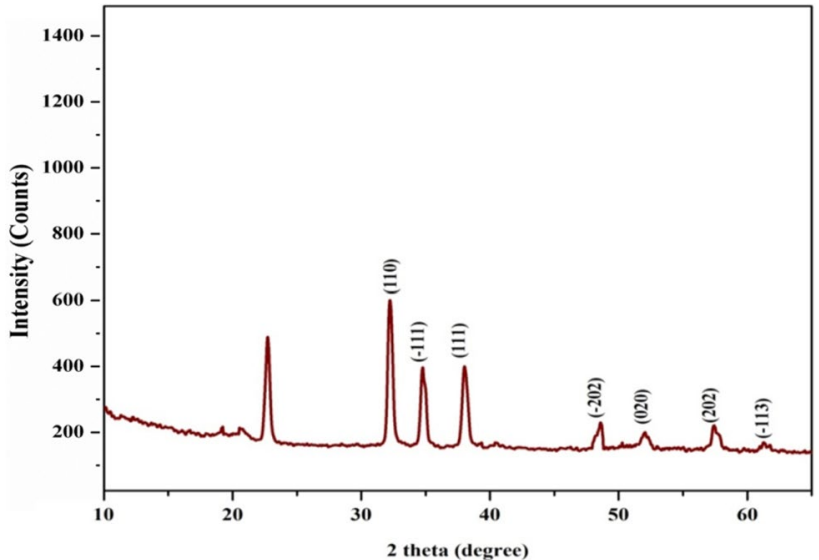

Fig. 4 XRD pattern of CuNPs 
$\mathrm{XRD}$ analysis was carried out to understand the nature of biosynthesized CuNPs, and the results are shown in Fig. 4. The XRD analysis shows a series of diffraction peaks at 32.77, 34.66, 38.72, 48.20, 52.24, 57.35 and $61.27(2 \theta)$ corresponding to $(110),(-111),(111),(-202)$ (020), (202) and (-113) planes, respectively, which are in good agreement with the diffraction data card JCPDS No. 05-0661. The average crystal size of $60 \mathrm{~nm}$ was calculated from Scherer equation. The XRD pattern of these peaks indicates the CuNPs is crystalline in nature, and one of the unassigned peaks were observed, it may be due to the fewer vibrating molecules in the rhizome extract. The XRD diffraction patterns showed in this study are in high-quality agreement with the previous research reported for the biosynthesis of CuNPs $[2,26]$.

Antioxidant activity of rhizome and CuNPs were estimated semi-quantitatively by a rapid DPPH staining method using TLC. Samples were applied as a dot on a TLC layer that was then stained with DPPH solution (Fig. 5a). The appearance of white colour spot vs. a purple background has a potential value for the indirect evaluation of the antioxidant capability of rhizome and CuNPs in the dot blots. Biosynthesized CuNPs showed high antioxidant potential $(2.5 \mathrm{~cm})$ comparing with the rhizome extract $(1.5 \mathrm{~cm})$ [29]. The bactericidal activity of synthesized CuNPs was investigated against MDR S. Typhi human bacterial pathogen which shown in Fig. 5b. In this study, the CuNPs at 5 doses (1-5 mM) along with rhizome extract and was examined. The bactericidal result indicates that the growth inhibition noticed was minimum inhibition found in $2 \mathrm{mM}$ and maximum observed in $10 \mathrm{mM}$ of CuNPs. The strong bactericidal activity of CuNPs against MDR Salmonella enterica serovar Typhi noticed that the increasing concentrations of CuNPs effectively encountered the bacterial population. The results are consistent with studies reporting the antibacterial activity of CuNPs $[8,36]$. Tover Corona et al. [34] reported that the antibacterial activity of CuNPs depends both on the surface on released ions and/or accumulated in the cell wall membrane caused permeability, resulting in bacteria lysis, through the release of lipopolysaccharide and membrane protein channels. Kaviya et al. [12] reported that the CuNPs may collapse the structure of the cell membrane of the bacteria resulting in bacteria lysis.

The photocatalytic activity (PCA) of the biosynthesized CuNPs was evaluated using methylene blue (MB). The UV spectrum of MB has an absorption maximum at 664 and $294 \mathrm{~nm}$. Figure $5 \mathrm{c}$ showed the degradation efficiency of the MB on the rhizome extract mediated synthesized CuNPs as photocatalysts as a behavior of reaction time. The percentages of dye degradation by CuNPs under the source of sunlight have obtained about $90 \%$ after $75 \mathrm{~min}$.
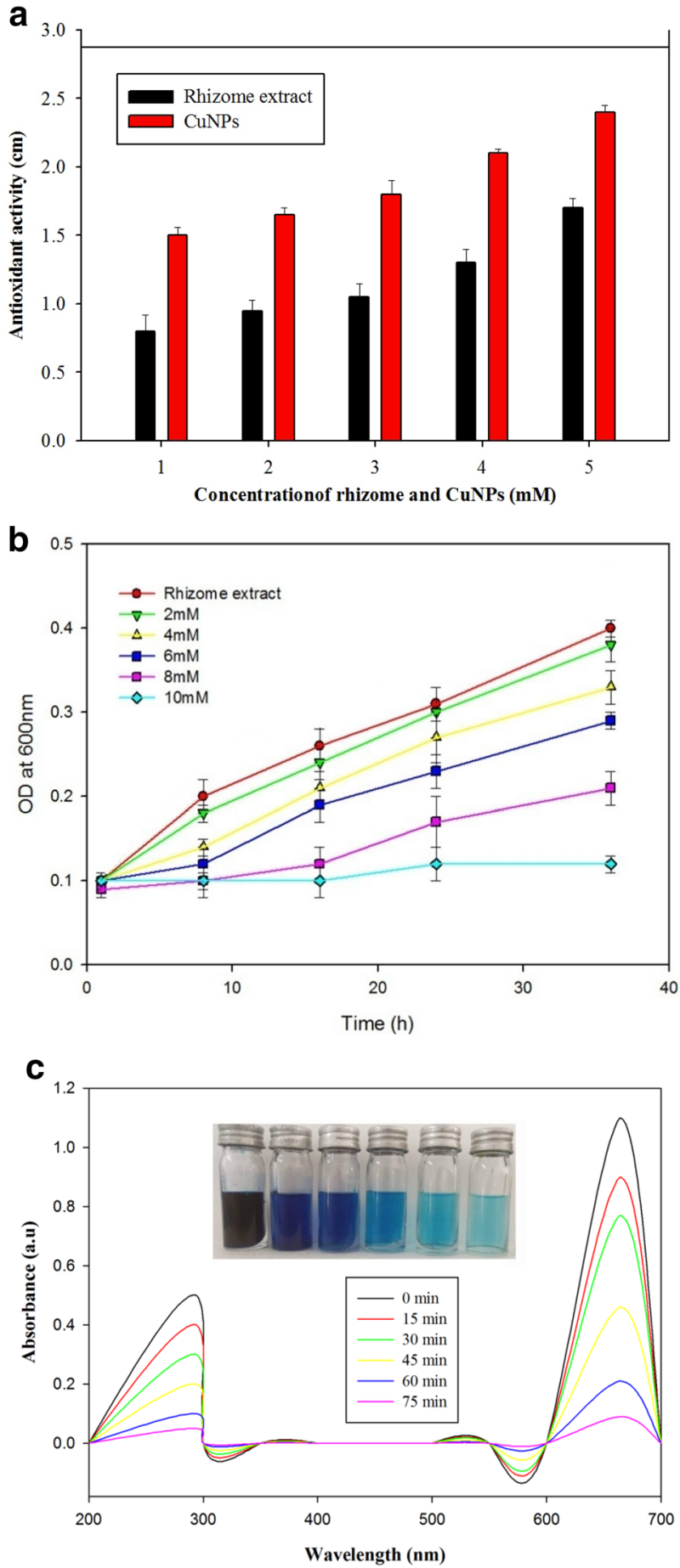

Fig. 5 a Antioxidant activity of rhizome extract and CuNPs, b Antibacterial activity of CuNPs against MDR bacteria c spectrum of photodegradation of methylene blue

Earlier reports on photocatalytic investigate revealed that the PCA of the CuNPs would depend on the crystalline structure, morphology, and size of the particles [35]. 


\section{Conclusions}

In summary, CuNPs were synthesized successfully using a simple, eco-friendly, rapid green methods using rhizome extract of $C$. epigaeus. The biogenic CuNPs were spherical in shape and crystalline nature with effective antibacterial activity against multidrug-resistant $S$. typhi. The green engineered CuNPs showed potential bactericidal activity against the human pathogen. The green synthesized CuNPs showed very good photocatalytic efficiency against methylene blue dye. It is suggested that the CuNPs obtained from the rhizome extract of $C$. epigaeus could be used as an effective antibacterial agent to control and/or kill the population of multi-drug resistant bacteria.

Acknowledgements This work is partially supported by the Department of Biotechnology, Mahendra Arts and Science College (Autonomous), and the Department of Science and Technology, Government of India (DST FIST sponsored-Ref. No. SR/FST/College-232/2014).

\section{Compliance with ethical standards}

Conflict of interest All authors declare that they have no conflict of interest.

\section{References}

1. Ajitha B, Reddy YAK, Kim MJ, Jeon HJ, Ahn CW (2016) Superior catalytic activity of synthesized triangular silver nanoplates with optimized sizes and shapes. Catal Sci Technol 6:8289-8299. https://doi.org/10.1039/C8CY00462E

2. Basith NM, Vijaya JJ, Kennedy LJ, Bououdina M (2014) Structural, morphological, optical, and magnetic properties of Ni-doped $\mathrm{CuO}$ nanostructures prepared by a rapid microwave combustion method. Mater Sci Semicond Process 17:110-118. https://doi. org/10.1016/j.mssp.2013.09.013

3. Chandrasekaran SA (2013) Novel single step synthesis, high efficiency and cost effective photovoltaic applications of oxidized copper nanoparticles. Sol Energy Mater Sol Cells 109:220-226. https://doi.org/10.1016/j.solmat.2012.11.003

4. Cuevas R, Duran N, Diez MC, Tortella GR, Rubilar O (2015) Extracellular biosynthesis of copper and copper oxide nanoparticles by Stereum hirsutum, a native white-rot fungus from chilean forests. J Nanomater. https://doi.org/10.1016/j.msec.2017.05.130

5. Devipriya D, Roopan SM (2017) Cissus quadrangularis mediated ecofriendly synthesis of copper oxide nanoparticles and its antifungal studies against Aspergillus niger, Aspergillus flavus. Mater Sci Eng C 80:38-44. https://doi.org/10.1016/j.msec.2017.05.130

6. Dinda G, Halder D, Vazquez-Vazquez C, Lopez-Quintela MA, Mitra A (2015) Green synthesis of copper nanoparticles and their antibacterial property. J Surf Sci Technol 31:117-122. https://doi. org/10.18311/jsst/2015/1709

7. El-Refai AA, Ghoniem GA, El-Khateeb AY, Hassaan MM (2018) Eco-friendly synthesis of metal nanoparticles using ginger and garlic extracts as biocompatible novel antioxidant and antimicrobial agents. J Nanostruct Chem 8(1):71-81. https://doi. org/10.1007/s40097-018-0255-8
8. Govarthanan M, Cho M, Park JH, Jung JS, Yi YJ, Kamala-Kannan S, Oh BT (2016) Cottonseed oil cake extract mediated green synthesis of silver nanoparticles and its antibacterial and cytotoxic activity. J Nanomater. https://doi.org/10.1155/2016/7412431

9. Govarthanan M, Selvankumar T, Mythili R, Sudhakar C, Selvam K (2017) Biosynthesis of silver nanoparticles from Spirulina microalgae and its antibacterial activity. Environ Sci Pollut Res. https ://doi.org/10.1007/s11356-017-9772-0

10. Hasan SS, Singh S, Parikh RY, Dharne MS, Patole MS, Prasad BL, Shouche YS (2008) Bacterial synthesis of copper/copper oxide nanoparticles. J Nanosci Nanotechnol 8(6):3191-3196. https:// doi.org/10.1166/jnn.2008.095

11. Jain PK, Huang X, El-Sayed IH, El-Sayed MA (2008) Noble metals on the nanoscale: optical and photothermal properties and some applications in imaging, sensing, biology, and medicine. Acc Chem Res 1(12):1578-1586. https://doi.org/10.1021/ar700 2804

12. Kaviya S, Santhanalakshmi J, Viswanathan B, Muthumary J, Srinivasan K (2011) Biosynthesis of silver nanoparticles using Citrus sinensis peel extract and its antibacterial activity. Spectrochim Acta A Mol Biomol Spectrosc 79(3):594-598. https:// doi.org/10.1016/j.saa.2011.03.040

13. Kayalvizhi S, Sengottaiyan A, Selvankumar T, Senthilkumar B, Sudhakar C, Selvam K (2020) Eco-friendly cost-effective approach for synthesis of copper oxide nanoparticles for enhanced photocatalytic performance. Optik. https://doi. org/10.1016/j.ijleo.2019.163507

14. Khanna PK, Gaikwad S, Adhyapak PV, Singh N, Marimuthu R (2007) Synthesis and characterization of copper nanoparticles. Mater Lett 61:4711-4714. https://doi.org/10.1016/j.matle t.2007.03.014

15. Khani R, Roostaei B, Bagherzade G, Moudi M (2018) Green synthesis of copper nanoparticles by fruit extract of Ziziphus spinachristi (L.) Willd.: application for adsorption of triphenylmethane dye and antibacterial assay. J Mol Liq 255:541-549

16. Ko J, Kim S, Hong J, Ryu J, Kang K, Park C (2012) Synthesis of graphene-wrapped $\mathrm{CuO}$ hybrid materials by $\mathrm{CO}_{2}$ mineralization. Green Chem 14:2391-2399. https://doi.org/10.1039/C2GC3 $5560 \mathrm{D}$

17. Kumar P, Govindaraju M, Senthamilselvi S, Premkumar K (2013) Photocatalytic degradation of methyl orange dye using silver (Ag) nanoparticles synthesized from Ulva lactuca. Colloids Surf B Biointerfaces 103:658-661. https://doi.org/10.1016/j.colsu rfb.2012.11.022

18. Maryam B, Zeinab SZ, Bahar K (2016) Green synthesis of copper oxide nanoparticles/clinoptilolite using Rheum palmatum L. root extract: high catalytic activity for reduction of 4-nitro phenol, rhodamine B, and methylene blue. J Sol-Gel Sci Technol. https ://doi.org/10.1007/s10971-016-4239-1

19. Mohana S, Sumathi S, Vinoth KP (2020) Agaricus bisporus mediated biosynthesis of copper nanoparticles and its biological effects: an in-vitro study. Colloids Interface Sci Commun 35:100254. https://doi.org/10.1016/j.colcom.2020.100254

20. Mukhopadhyay R, Kazi J, Debnath MC (2018) Synthesis and characterization of copper nanoparticles stabilized with Quisqualis indica extract: evaluation of its cytotoxicity and apoptosis in B16F10 melanoma cells. Biomed Pharmacother 97:1373-1385. https://doi.org/10.1016/j.biopha.2017

21. Nagar N, Devra V (2018) Green synthesis and characterization of copper nanoparticles using Azadirachta indica leaves. Mater Chem Phys. https://doi.org/10.1016/j.matchemphy s.2018.04.007

22. Narendra K, Swathi J, Sowjanya KM, Rathnakar Reddi KVN, Maruthi Varaprasad M, Padmavathi Ch, Venkata RG, Krishna Satya A (2015) Studies on chemical and biological properties of 
Bryonia epigaea (Rottler). J Med Plants Res 9(22):664-673. https ://doi.org/10.5897/JMPR2015.5524

23. Praburaman $L$, Jang JS, Govarthanan $M$, Sengottaiyan A, Manoharan K, Cho KM, Cho M, Kamala-Kannan S, Oh B (2015) Piper betle-mediated synthesis, characterization, antibacterial and rat splenocyte cytotoxic effects of copper oxide nanoparticles. Artif Cells Nanomed Biotechnol. https://doi.org/10.3109/21691 401.2015.1029630

24. Rajesh KM, Ajitha B, Ashok Kumar Reddy Y, Suneetha Y, Sreedhara Reddy P (2017) Assisted green synthesis of copper nanoparticles using Syzygium aromaticum bud extract: physical, optical and antimicrobial properties. Optik 154:593-600. https://doi. org/10.1016/j.ijleo.2017.10.074

25. Rajeshwari S, Pattanathu KSM, Rahman P, Rajiv HA, Salam VR (2014) Biogenic copper oxide nanoparticles synthesis using Tabernaemontana divaricate leaf extract and its antibacterial activity against urinary tract pathogen. Spectrochim Acta A Mol Biomol Spectrosc 133:178-181. https://doi.org/10.1016/j. saa.2014.05.048

26. Rehana D, Mahendiran D, Senthil Kumar R, Rahiman AK (2017) Evaluation of antioxidant and anticancer activity of copper oxide nanoparticles synthesized using medicinally important plant extracts. Biomed Pharmacother 89:1067-1077. https://doi. org/10.1016/j.biopha.2017.02.101

27. Ren G, Hu D, Cheng EW, Vargas-Reus MA, Reip P, Allaker RP (2009) Characterization of copper oxide nano particles for antimicrobial applications. Int J Antimicrob Agents 33(6):587-590. https://doi.org/10.1016/j.ijantimicag.2008.12.004

28. Sankar R, Maheswari R, Karthik S, Shivashangari KS, Ravikumar V (2014) Anticancer activity of Ficus religiosa engineered copper oxide nanoparticles. Mater Sci Eng C 44:234-239. https://doi. org/10.1016/j.msec.2014.08.030

29. Selvam K, Rathika R, Govarthanan M, Agastian P, Selvankumar T, Sengottaiyan A (2013) Antioxidant potential and secondary metabolites in Ocimum sanctum L. at various habitats. J Med Plants Res 7(12):706-712. https://doi.org/10.5897/JMPR11.446

30. Selvam K, Sudhakar C, Govarthanan M, Thiyagarajan P, Sengottaiyan A, Senthilkumar B, Selvankumar T (2017) Eco-friendly biosynthesis and characterization of silver nanoparticles using Tinospora cordifolia (Thunb.) Miers and evaluate its antibacterial, antioxidant potential. J Radiat Res Appl Sci 10:6-12. https://doi. org/10.1016/j.jrras.2016.02.005
31. Selvam K, Sudhakar C, Selvankumar T, Senthilkumar B (2020) Facile approach for phytosynthesis of gold nanoparticles from Corallocarbus epigaeus rhizome extract and their biological assessment. Mater Res Express. https://doi.org/10.1088/20531591/ab608f

32. Singh J, Kumar V, Kim KH, Rawat M (2019) Biogenic synthesis of copper oxide nanoparticles using plant extract and its prodigious potential for photocatalytic degradation of dyes. Environ Res 177:108569

33. Shankar R, Manikandan $P$, Malarvizhi V, Fathima T, Shivashangari KS, Ravikumar V (2014) Green synthesis of colloidal copper oxide nanoparticles using Carica papaya and its application in photocatalytic dye degradation. Spectrochim Acta A Mol Biomol Spectrosc 121:746-750. https://doi.org/10.1016/j.saa.2013.12.020

34. Tovar-Corona A, Lobo-Sanchez MA, Herrera-Perez JL, Zanella R, Rodriguez-Mora Jl, Vazquez-Cuchillo O (2018) Green synthesis of copper (0) nanoparticles with cyanidine-0-3- glucoside and its strong antimicrobial activity. Mater Lett 211:266-269. https ://doi.org/10.1016/j.matlet.2017.10.020

35. Vasantharaj $S$, Sathiyavimal $S$, Saravanan $M$, Senthilkumar $P$, Kavitha G, Shanmugavel M, Manikandan E, Pugazhendhi A (2018) Synthesis of eco-friendly copper oxide nanoparticles for fabrication over textile fabrics: characterization of antibacterial activity and dye degradation potential. J Photochem Photobiol B. https://doi.org/10.1016/j.jphotobiol.2018.12.026

36. Vijay Kumar PPN, Shameem U, Kollu P, Kalyani RL, Pammi SVN (2015) Green synthesis of copper oxide nanoparticles using Aloe vera leaf extract and its antibacterial activity against fish bacterial pathogens. Bio Nano Sci. https://doi.org/10.1007/s1266 8-015-0171-z

37. Zhang Q, Zhang $K$, Xu D, Yang G, Huang H, Nie F, Liu C, Yang S (2014) CuO nanostructures: synthesis, characterization, growth mechanisms, fundamental properties, and applications. Prog Mater Sci 60(1):208-237. https://doi.org/10.1016/j.pmats ci.2013.09.003

Publisher's Note Springer Nature remains neutral with regard to jurisdictional claims in published maps and institutional affiliations. 